considered, that prior infection with one virus affords protection against closely related ones.

The main conclusions from this study can be summarized as follows: The variation in COVID-19 per capita death rates in various countries appears to be of natural origin, namely immunity status of the population arising from its history of exposure to infections. This factor accounts for orders of magnitude differences in per capita deaths due to the COVID-19 pandemic, and needs to be considered in formulation of policies for the management of the pandemic. Policies that restrict economic activity to avoid overloading of health infrastructure are appropriate only where the expected rates of serious infection and death are substantial. It would obviously not deliver benefits commensurate with costs in countries where the per capita deaths are low, as a result of pre-existing immunity.

Declaration: The authors declare no competing interests.

1. Haridas, A. and Prathap, G., Are COVID-19 rates inversely proportional to the death rates by flu and influenza?, 2020; https://www. researchgate.net/publication/340262817; doi:10.13140/RG.2.2.16795. 21285.

2. Skountzou, I. et al., Immunity to pre-1950 H1N1 influenza viruses confers cross protection against the pandemic swine-origin 2009 A (H1N1) influenza virus. J. Immunol., 2010, 185, 1642-1649.

3. Priyamvada, L. et al., Human antibody responses after dengue virus infection are highly cross-reactive to Zika virus. Proc. Natl. Acad. Sci. USA, 2016, 113, 7852-7857.

4. Barry, J. M., Viboud, C. and Simonsen, L., Cross-protection between successive waves of the 1918-1919 influenza pandemic: epidemiological evidence from US Army camps and from Britain. $J$. Infect. Dis., 2008, 198, 1427-1434.

5. Morales, K. F., Paget, J. and Spreeuwenberg, P., Possible explanations for why some countries were harder hit by the pandemic influenza virus in 2009 - a global mortality impact modeling study. BMC Infect. Dis., 2017, 17, 642-644.

6. Short, K. R., Kedzierska, K. and van de Sandt, C. E., Back to the future: lessons learned from the 1918 influenza pandemic. Front. Cell. Infect. Microbiol., 2018, 8, 343; doi:10.3389/fcimb.2018. 00343.

7. Prathap, G., Scale-dependent stratification: a skyline-shoreline scatter plot. Scientometrics, 2019, 119(2), 1269-1273.

Received 25 April 2020; revised accepted 17 June 2020

doi: $10.18520 / \mathrm{cs} / \mathrm{v} 119 / \mathrm{i} 3 / 535-539$

\section{Space-based observations on the impact of COVID-19-induced lockdown on aerosols over India}

\author{
Yogesh Kant*, Debashis Mitra and \\ Prakash Chauhan \\ Indian Institute of Remote Sensing, \\ Indian Space Research Organisation, Department of Space, \\ Dehradun 248 001, India
}

The lockdown period in India due to COVID-19 came into effect from 25 March 2020 onwards. The present study analyses the changes and trends in aerosol optical depth (AOD) levels during the last few months and particularly during lockdown period. MODIS observations showed an average reduction of $20-37 \%$ in aerosol loading during the lockdown period (25 March-3 May 2020), compared to 2017-2019 across India. A clear-cut and drastic reduction in AOD (which includes both PM2.5 and PM10) was observed at many places across India, in particular over North India (46\%), eastern Indo-Gangetic Plains (42\%) and peninsular India $(30 \%)$. Maximum decrease in AOD was seen during 25 March to 5 April 2020 with values as low as $0.18-0.22$, which are $72-87 \%$ lower than the February-March 2020 level. AOD then slightly increased in the third week of April due to stubble burning and a few cloudy days, and then fell subsequently. Ground measurements on air pollutants at selected Indian cities revealed reduction of $40-50 \%$ in surface concentration prior to the lockdown period. Thus, study shows a clear-cut improvement in air quality leading to significant improvement in visibility and more blue skies.

Keywords: Aerosol optical depth, air quality, coronavirus, lockdown.

THE coronavirus (COVID-19) has infected over 4.8 million people worldwide causing more than 0.318 million deaths and spreading to all corners of the Earth (as on 19 May 2020) ${ }^{1}$. Depending on the level of infection and impact of COVID-19, each country has been adopting different levels of intervention, including national and international road, rail and air travel, complete or partial lockdown of people's movement, industrial and economic activity, markets and social activities. Since the reporting of the deadly coronavirus from Wuhan, China on 31 December 2019 and its subsequent spread to various parts of the world, the World Health Organisation (WHO) declared it as pandemic on 12 March 2020. The first case of COVID-19 in India was reported on 30 January 2020, which rose to 110 cases by 15 March and $500+$ active cases by 24 March 2020 (ref. 2). From 25 March 2020 onwards the Government of India (GoI) announced a

*For correspondence. (e-mail: ykanty@gmail.com) 


\section{RESEARCH COMMUNICATIONS}
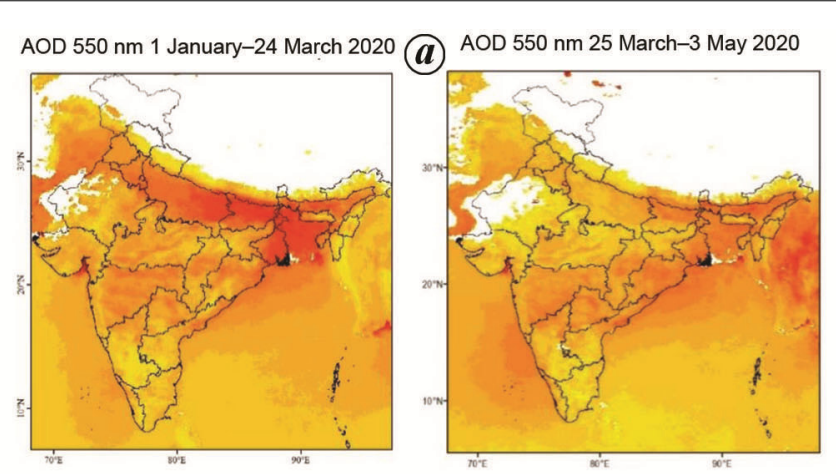

AOD $550 \mathrm{~nm} 1$ January-24 March 2018
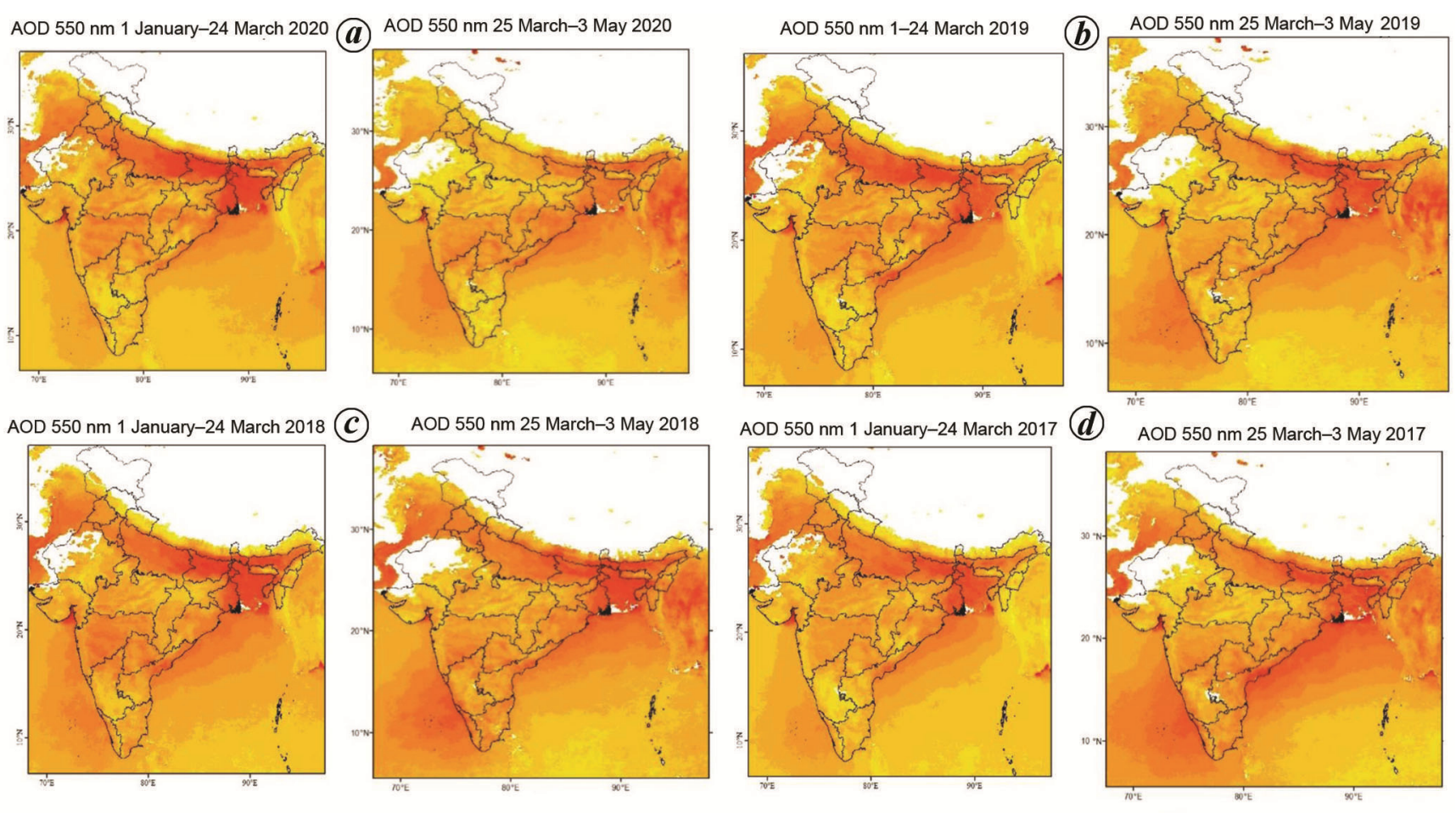

苋

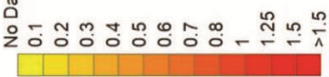

Figure 1. Spatial distribution of aerosol optical depth (AOD) over India during pre-lockdown (PLD) and during lockdown (DLD) in (a) 2020, (b) 2019, (c) 2018 and (d) 2017.

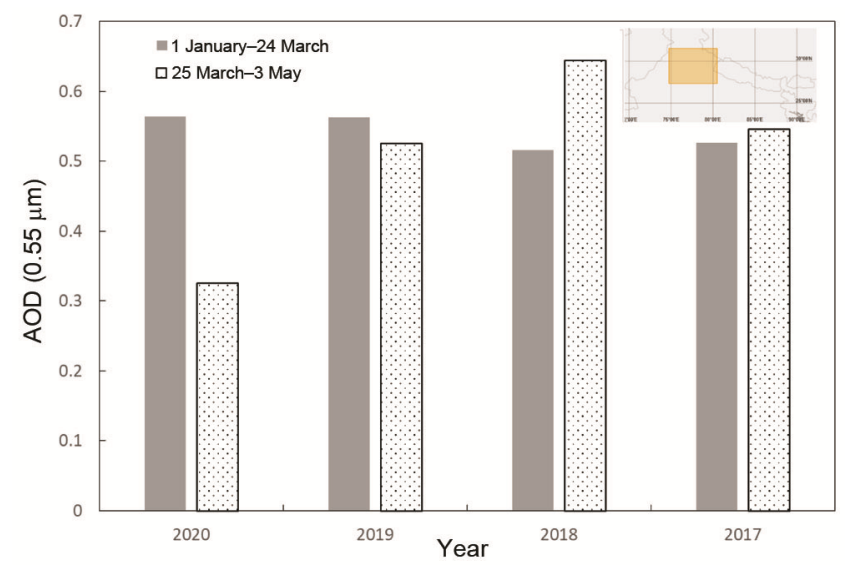

Figure 2. Average AOD over northern India during PLD and DLD of 2020 , and its comparison with the years of 2017, 2018 and 2019 over the same time period.

lockdown for its 1.3 billion people for three weeks. Subsequently, keeping in view the spread of the virus, GoI extended the lockdown further 19 days from 15 April till 3 May 2020. During this period, except agricultural and few essential economic activities, everything was under lockdown. From 4 May 2020 onwards, the lockdown was partially eased and commercial, industrial, agricultural, market, business activities were relaxed in those areas where spread of the virus had been contained.

Despite the severe impact of lockdown on people's social life, mobility and economy, there are reports in India that this has temporarily improved environmental conditions $^{3,4}$. According to air quality index data from the Central Pollution Control Board (CPCB), New Delhi of 103 cities across India, 23 of them have recorded good air quality, and 65 cities have recorded satisfactory air quality during the lockdown period. The lockdown improved air quality index to satisfactory levels in nearly $90 \%$ of the 103 cities monitored ${ }^{5}$. This is significant news because air pollution is the single largest environmental health risk globally. The adverse impacts of air pollutants like aerosol particulate matter $(\mathrm{PM})$, nitrous oxide $\left(\mathrm{NO}_{2}\right)$, tropospheric ozone $\left(\mathrm{O}_{3}\right)$ and sulphur dioxide $\left(\mathrm{SO}_{2}\right)$ on human health are well studied ${ }^{6}$. Both $\mathrm{NO}_{2}$ and aerosol particulate matter have been linked to heart and lung diseases and may impact lung function. Hence air pollution may also affect the mortality rate of COVID-19. Breathing air with a high concentration of aerosol particulates (PM10, PM2.5) can irritate airways in the human respiratory system. Clean air could aid in the battle against the virus as air pollution makes people more vulnerable to lung disease. Outdoor and household air pollution worldwide causes 4.2 million and 3.8 million 


\section{RESEARCH COMMUNICATIONS}

premature deaths respectively ${ }^{7}$, of which 1.2 million premature deaths occur in India ${ }^{8}$. Currently, in India a sharp drop in complaints of patients with respiratory problems is noticed ${ }^{5}$. The present study focuses on changes in air quality by analysing spatial distribution and variation in aerosol optical depth (AOD) in the last few months over the country.

Daily level-2 MODIS Aqua and Terra AOD data at $0.1^{\circ}$ resolution over the Indian region were downloaded and processed (mosaicking and daily mean) from 1 January to 3 May for the years 2017, 2018, 2019 and 2020. In order to understand the trend and possible changes in air quality, we used two time periods, one from 1 January to 24 March as pre-lockdown (PLD) and another from 25 March to 3 May as during lockdown (DLD). We examined daily changes in AOD from 1 January to 3 May for 2017-2020 to study the effect of lockdown on its concentration.

In addition, MODIS active fire product at $1 \mathrm{~km}$ resolution - both Terra and Aqua, over the Indian region was used for assessing fire events during 1 March to 31 May for 2017, 2018, 2019 and 2020 (till 15 May 2020). The MODIS collection 6.0 standard active fire location product was extracted from Fire Information for Resource Management System (FIRMS), NASA database, which is produced using thermal anomalies at infrared wavelengths $(4 \text { and } 11 \mu \mathrm{m})^{9}$. The confidence level of estimation was classified as $0-29 \%$ for low, $30-70 \%$ for nominal and $80-100 \%$ for high fire events. The fire occurrences during this period were primarily due to forest fires in Himachal Pradesh and Uttarakhand, and stubble burning after rabi crop harvest in Punjab, Haryana, Uttar Pradesh and Bihar. These two activities involve human interference. The aim of this study was to determine whether there was any significant change during this lockdown period.

During the lockdown period, daily average air temperature range over North India was between $26^{\circ} \mathrm{C}$ and $32^{\circ} \mathrm{C}$, and wind speed was moderately calm at an average of 4 $7 \mathrm{~m} / \mathrm{s}$, with few rainy days (except 1 or 2 days of $0.6 \mathrm{~mm}$ rainfall). Also, Saharan dust which is active during this period (April-May) was not noticed during this year ${ }^{10}$. Hence, meteorology did not play a major role in dispersing air pollutants from one place to another.

Figure 1 shows the spatial distribution of AOD during the PLD and DLD time period in 2017-2020. The spatial distribution shows that there is drastic decrease of 18-30\% aerosol loading during DLD compared to PLD period of 2020. This decrease is clearly visible over the northern, Indo-Gangetic Plains (IGP) and peninsular regions, whereas AOD did not substantially decrease over the central-eastern region. Overall aerosol loading shows decrease of $21 \%-37 \%$ compared to the same time period of DLD of 2017-2019. Over North India average AOD during DLD is $42 \%$ reduced from PLD period. If we compare the DLD period of 2020 to the same period of
2017-2019, AOD loading is reduced by $46 \%$ over North India, reduced by $42 \%$ over eastern IGP and by $30 \%$ over peninsular India. During lockdown, North India and IGP experienced drastic reduction in aerosol loading due to reduced biomass burning, stubble burning, dust events and industrial processes (only essential goods) compared to earlier years. Similarly, over peninsular India, the reduction in aerosol loading was mainly due to reduction in industrial activities, vehicular movement and other anthropogenic activities.

The AOD anomaly map of 2020 (25 March-3 May) from average of 2017-2019 shows a clear-cut reduction in aerosol levels between 0.01 and 0.3 over North India and IGP, and between 0.01 and 0.12 over peninsular India with nominal increase of $0.01-0.08$ over the central and central-eastern regions (Figure 3 ). Figure $4 a$ depicts the time-series analysis of aerosol loading over northern India from 1 January to 12 May during 2017-2020. A consistent and drastic reduction in AOD is seen from 25 March 2020 onwards (DLD). The AOD values are also observed to be low compared to the three years average AOD values over the region. From the weekly series analysis, it is observed that the maximum decrease in AOD is seen during 29 March to 4 April 2020, with AOD values as low as 0.18 (Figure $4 \mathrm{~b}$ ). AOD during the lockdown period from 25 March to 5 April 2020 is observed to be the lowest in the range $0.18-0.22$. This decrease in aerosol loading is around $72-87 \%$ lower than the February-March 2020 level. Such low AOD levels has not

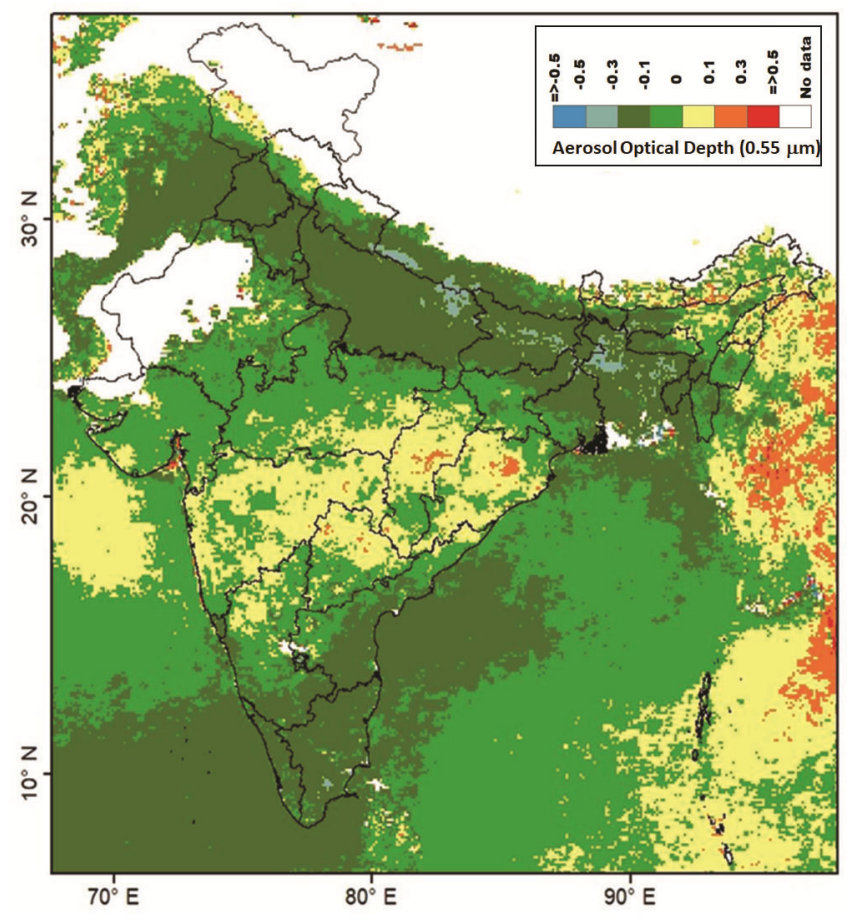

Figure 3. AOD anomaly in 2020 (25 March-3 May) with average for 2017-2019 during the same time period. 

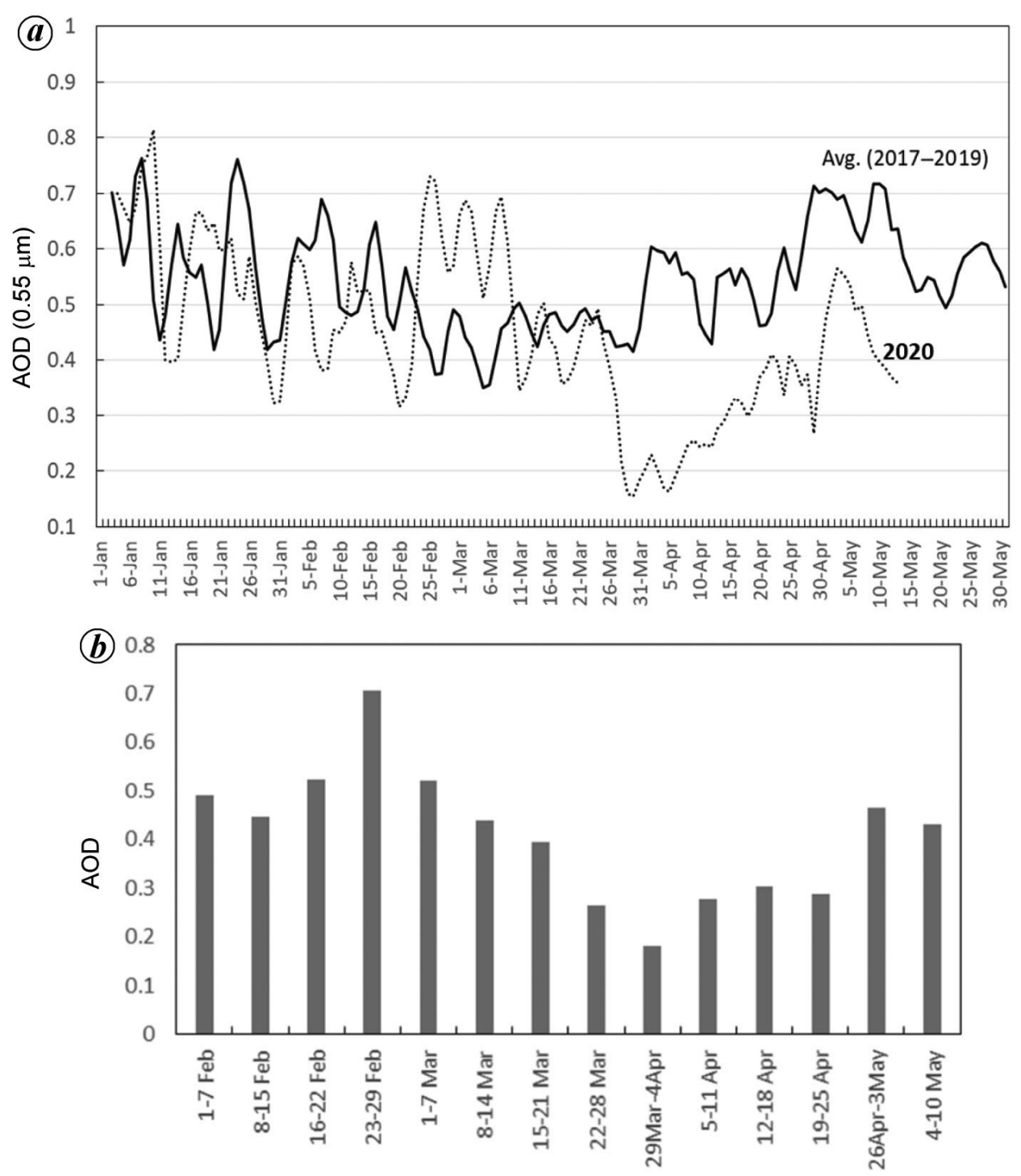

Figure 4. $\boldsymbol{a}$, Time-series analysis over northern India during 2020 and its comparison with the period 2017-2019. $\boldsymbol{b}$, Weekly variation of AOD from February-May 2020.

been reported earlier over the region during these months ${ }^{11}$. During the third week of April 2020, AOD slightly increased to $0.4-0.55$ over the northern region due to few local stubble burning activities and some cloudy days, and then decreased subsequently. In spite of this, the overall AOD values from 25 March 2020 onwards till May are at its lowest corresponding to the three years AOD average (Figure $4 a$ ).

However, this year due to the lockdown, burning activities are few. On the contrary, every year over northern India, during the time period April-May, dust episodes (over Rajasthan, Punjab, Haryana, Delhi, central and eastern IGP), rabi stubble burning (Punjab, Haryana and Uttar Pradesh) and forest fires (Uttarakhand and Himachal Pradesh) are frequently observed. However, due to the current lockdown scenario, these events have not been seen in 2020 . Hence, there is consistent reduction of $52 \%$ in AOD during 25 March to 25 April 2020 compared to the same period in 2017-2019 (Figure 4).

Figure 5 shows MODIS active fire maps over India during 1 March to 31 May for 2017, 2018, 2019 and 2020 (1 March-15 May). The maps clearly show that the seasonal fire events during 2020 have decreased to very low level compared to previous years. There is observed reduction of fire occurrences: on India basis (19.7\%), Uttar Pradesh (75.6\%), Punjab (75.8\%), Haryana (71.8\%), Bihar (64.5\%), Uttarakhand $(94.2 \%)$ and Himachal Pradesh $(84.0 \%)$. As these fires are responsible for emissions of aerosol particulate matter and trace gases $\left(\mathrm{NO}_{2}\right.$ and $\left.\mathrm{SO}_{2}\right)$, with reduction in the fire events, local emissions have been curtailed. However, analysis of air mass wind trajectories reveals that emissions from forest fires in Myanmar have directly influenced the central and central-eastern regions of India. Hence during April-May 
RESEARCH COMMUNICATIONS
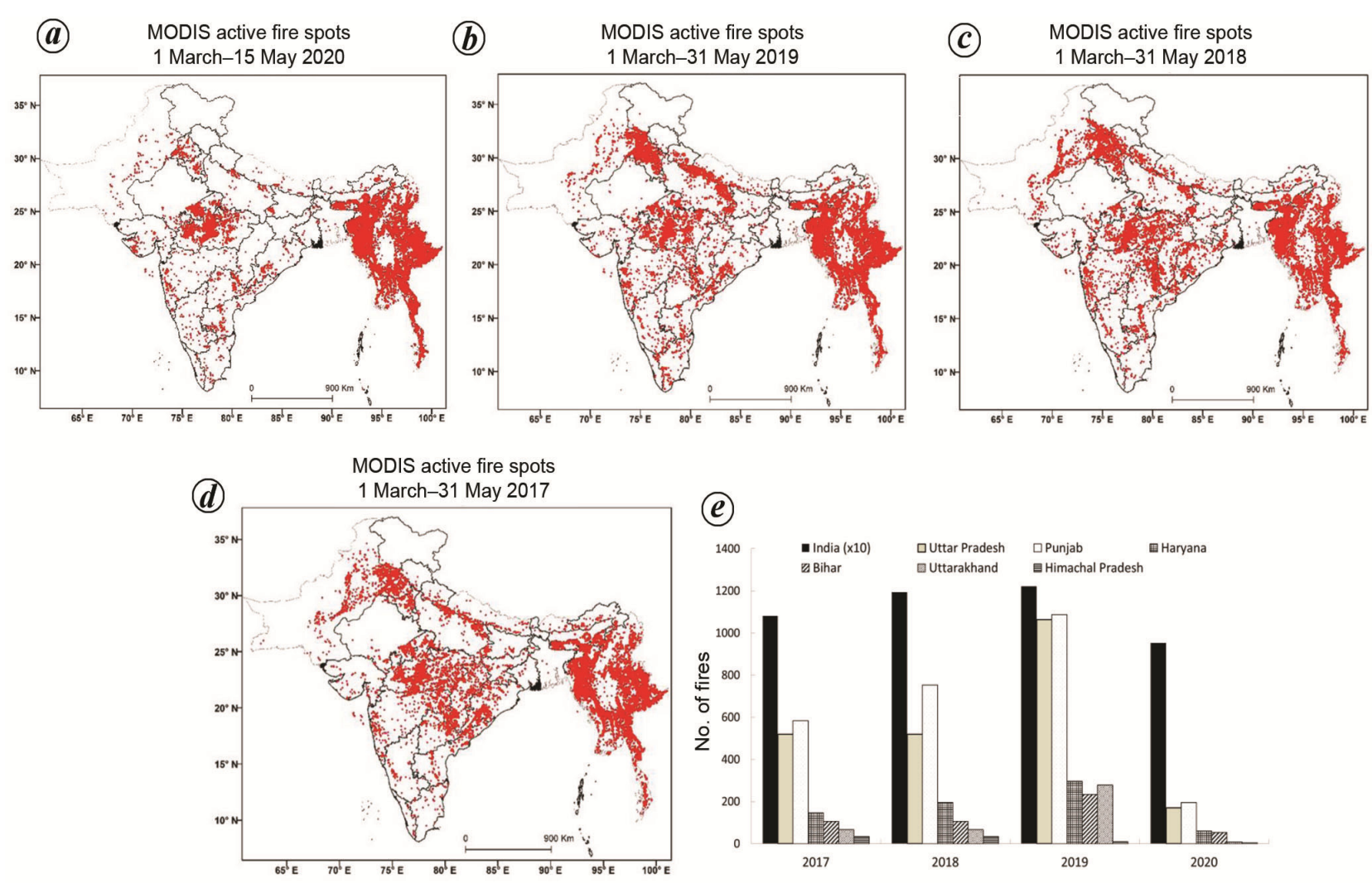

Figure 5. MODIS active fire points: (a) 2020, (b) 2019, (c) 2018 and (d) 2017. (e) Number of fires over different regions of northern India (1 March-15 May 2020).
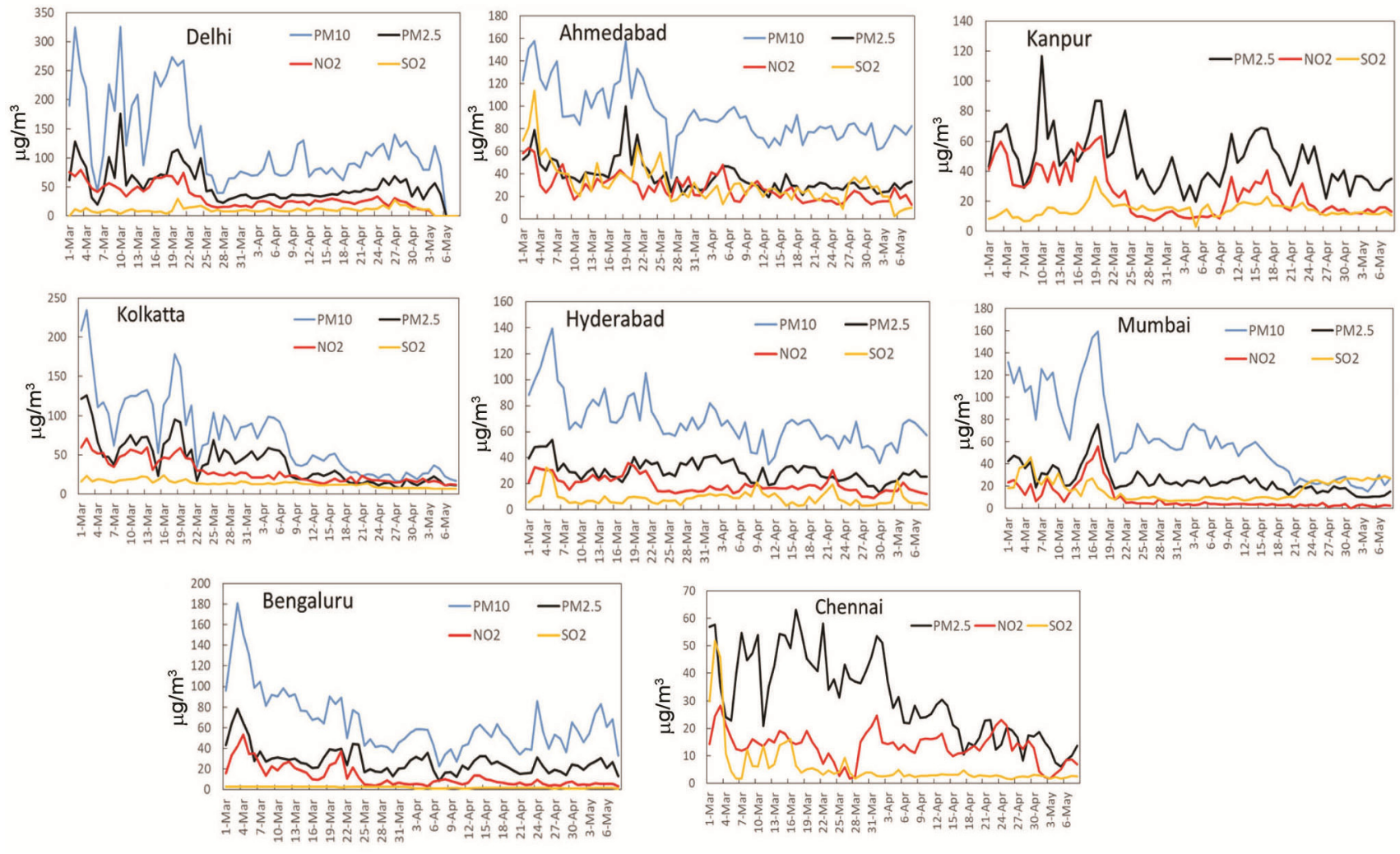

Figure 6. Surface-level concentration of air pollutants over selected Indian cities (data courtesy: Central Pollution Control Board). 
2020 , there is a clear impact of these fires on AOD over these regions (Figure 1).

The ground-level measurement of air pollutants (PM10, PM2.5, $\mathrm{NO}_{2}$ and $\mathrm{SO}_{2}$ ) by $\mathrm{CPCB}$ across selected cities over India were analysed (Figure 6). During the lockdown period, PM10, PM2.5 and $\mathrm{NO}_{2}$ show reduction of around $40-50 \%$ in surface concentration compared to pre-lockdown period.

This lockdown period has provided an opportunity to generate baseline data during minimal anthropogenic activity which is rare. Space-based observations along with ground data provide us a regional picture as well as hotspot detection.

The major findings of this study are summarized as follows:

- Satellite observations show an average reduction of $20-37 \%$ in aerosol loading (compared to the 20172019 period) across India.

- The AOD anomaly map of 2020 (25 March-3 May) from average of 2017-2019 for the same time period shows substantial reduction over North India, IGP and peninsular India, with slight increase over the centraleastern region.

- Weekly series analysis revealed maximum decrease in AOD during 29 March to 4 April 2020, with values as low as 0.18 .

- MODIS fire hotspots clearly show a drastic reduction of $65-90 \%$ in seasonal fire events over northern India and IGP during April-May 2020, compared to previous years, which is responsible for reduced anthropogenic emission of aerosols. Forest fires in Myanmar are also affecting the air quality over central and central-eastern regions of India.

- CPCB ground data on DLD period for PM10, PM2.5 and $\mathrm{NO}_{2}$ showed $40-50 \%$ reduction in surface concentration compared to the PLD period.

The reduction seen in air quality levels across India are only temporary due to lockdown measures. Such drastic steps of shutting down the economy for cleaning the air are not sustainable, but one can consider a scaled-down approach periodically. The current crisis has shown us that clear skies and breathable air can be rapidly achieved if concrete actions towards reducing the burning of fossil fuels are taken.

Declaration of competing interest: The authors declare that they have no known competing financial interests or personal relationships that could have influenced this work.

1. www.worldometers.info/coronavirus (accessed on 19 May 2020).

2. Timeline of the COVID-19 pandemic in India. International Edition. The world's largest coronavirus lockdown is having a dramatic impact on pollution in India. CNN, 1 April 2020; edition. cnn.com/2020/03/31/asia/coronavirus-lockdown-impact-pollutionindia-intl-hnk/index.html (accessed on 19 May 2020).

3. The Economic Times, Blue skies, reduced emissions only temporary, won't benefit environment in long run, 9 April 2020; economictimes.indiatimes.com/news/environment/pollution/blue-skiesreduced-emissions-only-temporary-wont-benefit-environment-inlong-run-experts/articleshow/75061943.cms (accessed on 19 May 2020).

4. Times of India, India's air gets cleaner after the lockdown, 8 April 2020; timesofindia.indiatimes.com/life-style/health-fitness/healthnews/indias-air-gets-cleaner-after-the-lockdown/articleshow/75040109.cms (accessed on 19 May 2020).

5. The Print, India Edition. India's dirty air has become cleaner after coronavirus lockdown. 8 April 2020; theprint.in/india/indias-dirtyair-has-become-cleaner-after-coronavirus-lockdown/397508/ (accessed on 19 May 2020).

6. WHO, Ambient air pollution: a global assessment of exposure and burden of disease, World Health Organization, Geneva, 2016.

7. World Health Organization, WHO Ambient (Outdoor) Air Quality Database. WHO, Geneva, 2018; who.int/phe/health_topics/ outdoorair/databases/cities/en/ (accessed on 19 May 2020).

8. GAHP, Annual report, Global Alliance on Health and Pollution, New York, 2018.

9. Giglio, L., Descloitres, J., Justics, C. O. and Kaufman, Y. J., An enhanced contextual fire detection algorithm for MODIS. Remote Sensing Environ., 2003, 87(2-3), 273-282.

10. Sarkar, S., Chauhan, A., Kumar, R. and Singh, R. P., Impact of deadly dust storms on air quality, meteorological and atmospheric parameters over northern parts on India. GeoHealth, 2019, 3(3), 67-80.

11. Saheb, D. S. et al., Impact of biomass burning on regional aerosol optical properties: a case study over northern India. J. Environ. Manage., 2019, 244, 328-343.

ACKNOWLEDGEMENTS. We thank GES-DISC Interactive Online Visualization and Analysis Infrastructure (Giovanni) for providing the MODIS data. We also thank the Central Pollution Control Board, New Delhi and Mr Ravi Teja (JNTU Kakinada) for help in data processing.

Received 13 May 2020; revised accepted 30 May 2020

doi: $10.18520 / \mathrm{cs} / \mathrm{v} 119 / \mathrm{i} 3 / 539-544$ 